\section{anthropology} \& materialism

\section{Anthropology \& Materialism}

A Journal of Social Research

Special Issue | I | 2017

Discontinuous Infinities

\title{
Eccentric Bodies
}

From Phenomenology to Marxism - Walter Benjamin's Reflections on Embodiment

\section{Léa Barbisan}

\section{(2) OpenEdition}

12 Journals

Electronic version

URL: http://journals.openedition.org/am/803

DOI: $10.4000 / a m .803$

ISSN: 2364-0480

\section{Publisher:}

CETCOPRA, CRASSH - Center for Research in the Arts Social Sciences and Humanities, Fakultät

Gestaltung - Universität der Künste Berlin

Electronic reference

Léa Barbisan, "Eccentric Bodies », Anthropology \& Materialism [Online], Special Issue | I| 2017, Online since 02 March 2017, connection on 02 May 2019. URL : http://journals.openedition.org/am/803 ; DOI : 10.4000/am.803

This text was automatically generated on 2 May 2019.

Tous droits réservés 


\title{
Eccentric Bodies
}

\author{
From Phenomenology to Marxism - Walter Benjamin's Reflections on \\ Embodiment
}

Léa Barbisan

\section{Introduction}

\author{
"On considère sa main sur la table, et il en résulte \\ toujours une stupeur philosophique. Je suis dans \\ cette main et je n'y suis pas" \\ Paul Valéry
}

1 In the epistolary debate between Theodor W. Adorno and Walter Benjamin about the latter's essay "The Storyteller" (first published in 1936), Adorno warns his friend against what he considers to be a dangerous tendency pervading the essay - an "undialectical ontology of the body". Significantly, he writes:

For all those points in which, despite our most fundamental and concrete agreement in other matters, I differ from you could be summed up and characterized as an anthropological materialism that I cannot accept. It is as if for you the human body represents the measure of all concreteness. ${ }^{1}$

2 He directly links Benjamin's lack of 'dialectics' with his faith in the human body's ability to function as the matrix of revolutionary forces. Adorno's evaluation of his friend's method (or lack thereof) is debatable, but, notably, he points out the importance of corporeality in Benjamin's political theory. More recently, studies by Uwe Steiner, Irving Wohlfarth, Gerhard Richter and Sigrid Weigel contributed to an appreciation of this aspect of Benjamin's thought. ${ }^{2}$ Although Benjamin does not dedicate any complete text to this theme, the human body and its representations play a pivotal role in his work - a guiding thread connecting his fragments on anthropology, written in the late 1910s, and his essays addressing processes of alienation in capitalist modernity, written in the 1930s. The purpose of this paper is to show how Benjamin's later utopia of a revolutionary "collective physis", ${ }^{3}$ which bears witness to his distinctive reception of Marxist theory, unfolds a line of thought initiated approximately ten years earlier, in a group of fragments wherein Benjamin sketches a peculiar phenomenology of embodiment. These 
early reflections on bodily awareness, clearly distinct from the analyses proposed by Max Scheler and Edmund Husserl, enable Benjamin to progressively develop a theory of political emancipation grounded on a critical examination of collective forms of embodiment.

\section{Leib and Körper. Walter Benjamin's Phenomenology of the Body}

\section{I.1. Elusive Identity}

3 In the second half of the 19th century, first with Arthur Schopenhauer, then with Friedrich Nietzsche, the body makes a decisive entrance on the German philosophical scene. ${ }^{4}$ Though their approach is different, Schopenhauer and Nietzsche describe the human being as fundamentally embodied and question the traditional dualistic conception which exiled the body in the sphere of objects. As a philosophy student, Walter Benjamin is soon confronted with the questions raised by the redefinition of the problem of embodiment. As Uwe Steiner points out, during his time in Bern, Benjamin followed a seminar taught by the philosopher and psychologist Paul Häberlin, entitled "The Problem of Body and Soul". ${ }^{5}$ Häberlin's view on the matter did not make a lasting impression on Benjamin, yet the problem itself certainly triggered his interest. In the late 1910s and early 1920s, Benjamin writes a number of fragments addressing the experience the human being makes of her own body ("Perception and Body", "Death", "On Love and Related Matters", "On Horror", "Outline of the Psychophysical Problem"). When Benjamin writes these short texts, the question of the "lived body" (Leib), i.e. the body experienced as pertaining to the ego, as belonging to the sphere of subjectivity, becomes relevant.

4 The first philosophical movement which rigorously deals with bodily awareness is phenomenology, notably through the distinction it establishes between 'lived body' (Leib) and physical body or 'thing-body' (Körper). The split of the body impacts the reflection on identity, as the emergence of the 'lived body' on the fault line between the ego and the world, directly questions the traditional division between thought and matter, subject and object. Within the phenomenological movement itself, the first evaluations of this shift in perspective were not unequivocal. In his major work published in 1916, Formalism in Ethics and Non-formal Ethics of Value, Max Scheler stresses the importance of making "a sharp distinction between "lived body" and "thing-body" [der "Leib" und der "Körper"]". ${ }^{6}$ We can indeed perceive our body from the outside, as a thing belonging to the world - the body is then given as Körper. By contrast, the body given to us in "inner perception", the body "independent of, and, in order of givenness, prior to [...] any special kinds of outer perception", is called "Leib".? Our body appears to us both as Leib and as Körper, both as the matrix of our life and as a thing. And yet this rift in perception does not entail a cognitive rift, because

there exists a strict and immediate unity of identity between the inner consciousness which everyone has 'of' the existence and the hereness [Befinden] of the lived body [...] and the outer perception of one's lived body (as the body-thing). ${ }^{8}$

Although 'body-thing' (Körper) and 'lived body' (Leib) do not share the same mode of appearance, the undubitable fact of their identity prevails and safeguards the integrity of the individual. According to Scheler, the body can thus never appear as alien to ourselves, 
even when its mode of appearance is that of an object (Körper). It is immediately given as an inalienable part of our identity.

6 In the second book of Ideas Pertaining to a Pure Phenomenology and to a Phenomenological Philosophy: Studies in the Phenomenology of Constitution, written between 1912 and 1928 and first published after his death, Edmund Husserl, the founder of the phenomenological school, explores more profoundly the duality of the body, this "material thing of a certain nature which [...] makes up a fundamental component of the real givenness of the soul and the Ego". ${ }^{9}$ He remarks that our body perceived as physical body or thing (Körper) never appears to us as an object among objects, but as a "remarkably imperfectly constituted thing", since "certain of my corporeal parts can be seen by me only in a peculiar perspectival foreshortening and others (e.g., the head) are altogether invisible to me". ${ }^{10}$ Husserl, more than Scheler, accounts for the specific mode of appearance of the body as Körper. As an incomplete, misshapen object, it remains fundamentally unknowable to the ego whose intentions it performs. Our inability to visually cognise and recognise our own body is nevertheless compensated by the sense of touch, through which we can simultaneously feel the deepness of our body and the reliability of its epidermic surface. The "touch-sensings" compensate for the deficiency of sight, so that the monstrous entity "manifests itself immediately as my Body (Leib)". ${ }^{11}$ Husserl, like Scheler, though in a more reflected manner, bridges the gap between Körper and Leib, between thing and "soul", in order to ensure the ego's grip on its organ of perception and movement.

7 Although he could not have read Husserl's text as it was not published at that time, Benjamin's initial observation in "Perception and Body", a fragment written in 1918, is very similar to Husserl's note on the monstrous appearance of the lived body:

It is highly significant that our own body is in many ways inaccessible to us. We can see neither our face, nor our back, nor our entire head, the primary part of our body [...]. We rise up into the world of perception with our feet, but not our head. ${ }^{12}$

Benjamin however, in contrast to Scheler and Husserl, does not try to recenter the 'lived body' on the ego: he lets it disrupt the barrier between inside and outside, self and world, subject and object. In a longer text, "Outline of the Psychophysical Problem", Benjamin emphasizes the tensions running through the body, notably the one between the centripetal and centrifugal senses: while touch, as a centripetal sense, makes us aware of our body's limits, the centrifugal sense of sight literally opens us to our environment. Indeed, the center of our center of perception, our face, is blind to itself: it is a hole through which the world "breaks over us", ${ }^{13}$ filling us with its invasive presence, catching us in the ebb and flow of sensory stimuli. Benjamin insists on the "body's eccentricity": ${ }^{14}$ as soon as our own body intrudes into our perceptual field, we are confronted with the centrelessness of what we are accustomed to regard as our centre of perception. The headless, anamorphic figure we suddenly see radically questions the hierarchies between self and world by offering resistance to its assignation to the sphere of things (physical body/Körper) as well as to the sphere of the ego (lived body/Leib). Scheler and Husserl do not sufficiently question the coincidence between the body perceived as a thing (through 'outer perception' for Scheler, through sight for Husserl) and the body felt as a part of ourselves (through 'inner perception' for Scheler, through touch for Husserl): in the end, there is no doubt that physical body and lived body are one and the same entity, given to us through different modes of appearance. Benjamin, on the contrary, stretches the relation between Körper and Leib until it breaks: the body becomes the place where 
alienness (the object, the world, the outside) penetrates the sphere of the self and deeply disturbs its structure. The fragment "On Horror", written at the beginning of the 1920s, revolves around the idea of a split in the body, experienceable in states of profound absent-mindedness in which the spirit is pulled out of the body. What is left behind once the lived body (Leib) is taken away with the spirit it belongs to, is the Körper - a body the ego can neither recognize as a part of itself, nor dismiss as a mere thing. The Körper appears indeed as a "double"15 - a ghostly reduplication of myself which undermines the foundation of identity, because it is neither me nor alien to me. In this hallucinatory state, subjectivity is being haunted in its own territory by a presence that challenges its autonomy - a presence it represses but can never fully expel. In Benjamin's peculiar phenomenology, the body rooting the ego in the world is an unreliable, dual entity that the subject can never completely appropriate.

\section{I.2. Personal and Collective Body. Defining Ethical and Political Categories}

9 The fragment "Outline of the Psychophysical Problem", written around 1922, is principally devoted to the distinction between Leib and Körper. In this long fragment, Benjamin decisively leaves behind the phenomenological concepts of 'lived body' and 'thing-body' and offers a new assessment of corporeality. Although he seems to begin unsurprisingly with the polarity between the spiritual and the material (Geist and Leib), Benjamin does not resort to, either, a dualistic, or a unitarian interpretation of the relationship between body and mind, but postulates instead their radical identity. This perspective makes the question of the link between body and mind - be it understood as an antagonism or as a symbiosis - irrelevant: Geist and Leib are indeed one and the same object. The distinction between the two modes of embodiment - Körper and Leib - is soon revealed as the relevant one. The Leib has got its own temporality (the instant) and locality (shape). Both are marked by limitations. Yet the Leib is not to be confused with the personal body, since it is not a "substratum". ${ }^{16}$ It materializes at the intersection between individual life and historical process, thus determining the human being's experience in historical time and bearing witness to the entanglement of individual life with the collective process of history. The Körper, on the other hand, is described as the "substance of [ourselves]": ${ }^{17}$ it is absolutely ours and, at the same time, exceeds our perceptual faculty. Pain and pleasure, affects that are both diffuse and highly personal, make us aware of our Körper as a singular but limitless entity. Through the Körper, the human being is linked to a transcendent order, which Benjamin defines in the "Theological-Political Fragment" - thought to have been written around the same time as the "messianic order", in opposition to the "profane order" of history. ${ }^{18}$ The distinction that Benjamin institutes between Leib and Körper is grounded in the distinction established in the "Theological-Political Fragment" between history and theology, profane and transcendent order, politics and ethics. Ethics concerns the bond each human being forms with transcendence; its specific domain must therefore be distinguished from the sphere of politics, constituted by the immanent, collective process of history. Since history is a matter of politics, not of eschatology, ethics or religion cannot function as the basis for the political community. What, then, can bind human beings together and enable them to act collectively? 
10 The clear line of demarcation drawn between the profane, shared Leib and the transcendent, personal Körper allows Benjamin to develop an original theory of political emancipation. In "Outline of the Psychophysical Problem", Benjamin speaks indeed of the dissolution of the individual Leib, making way for the constitution of the "body [Leib] of mankind". ${ }^{19}$ Politics thus does not address individuals, communities, nations or classes; it concerns 'mankind' as a whole. This collective doesn't arise from the organisation of a coherent super-individuality binding together disparate individuals, but materializes as the overcoming of the boundaries on which the traditional concept of individuality is based: "In addition to the totality of all its living members, humanity is able partly to draw nature, the nonliving, plant and animal, into this life of the body of mankind, and thereby into this annihilation and fulfilment". ${ }^{20}$ The collective "happiness", which politics must strive to achieve, is not a state of balance and harmony, but a paradoxical process of decay and of blossoming. The "annihilation", interpreted by Benjamin as a "fulfilment", is the "downfall" of the self-sufficient individual. ${ }^{21}$ It is necessary for human beings, as individuals and as a species, to let go of the autarkic position they assume. The 'Leib of mankind' thus integrates non-human species as well as the inorganic elements of technology. Instead of conceiving of its body as the ideal of beauty and proportion and as an immutable biological substrate, mankind should become aware of the plasticity of its Leib. This collective body is indeed a constantly mutating whole, an expanding structure without a centre of command: its anarchic growth does not imply an increase of power. In the "Theological-Political Fragment", Benjamin argues that political emancipation is not about the constitution of a collective identity: it concerns a collective - a totality - that emerges from the progressive disintegration of identity. Politics is not a process through which order is created and boundaries are delineated: it is a movement that disrupts structures and challenges hierarchies.

11 Benjamin's daring phenomenology of the body announces the political writings of the late 1920 s and the 1930s. The phenomenological approach enables Benjamin to concentrate on the peculiar experience of embodiment and to radically break with the natural-scientific conception of the body as organism. Benjamin audaciously draws attention to the body's elusiveness: he does not seek to overcome the body's 'eccentricity', but instead exploits the rift that the splitting of the body as Leib and Körper opens in the individual. His utopia of a collective Leib is built on the duplicitous nature of a body that we cannot regard as the substratum of our identity, because it never fully belongs to us. Thereby, Benjamin radically defies the reactionary organicism, which, facing the frail Weimar Republic, tries to present itself as the only viable proposition for a coherent political community.

\section{The Masses. Politicising the Body}

\section{II.1. The Anatomy of Modernity. Bodies without Egos}

The mutations of experience in capitalist modernity become a privileged object of interest for Benjamin in the late 1920s and in the 1930s - a consequence of what he calls his "conversion to political theory"22 - more precisely: to Marxism. Combining his lasting interest in perception with a political analysis of economic exploitation, Benjamin develops a dialectical theory of alienation and emancipation closely tied to his early phenomenology of embodiment. Benjamin daringly wagers that the processes of 
depersonalization grounded on coerced forms of alienation from the body can contribute to a productive form of "self-alienation", ${ }^{23}$ paving the way for the constitution of collective bodies and, thus, possibly leading to a radical movement of emancipation.

One of the leitmotivs in his essay "On Some Motifs in Baudelaire" is the "shock experience" ${ }^{24}$ which structures the everyday perception of the human being immersed in the "big-city crowd". ${ }^{25}$ Submitted to a ceaseless flood of stimuli and forced to adapt to a constantly changing environment, human beings flowing through the crowd mobilize their peripheral mimetic faculties to the detriment of their cognitive capacities:

Moving through [the traffic of a big city] involves the individual in a series of shocks and collisions. At dangerous intersections, nervous impulses flow through him in rapid succession, like the energy from a battery. ${ }^{26}$

Edgar Allan Poe's short-story The Man of the Crowd, to which Benjamin devotes a chapter of his essay on Baudelaire, describes from an overhanging standpoint the gesticulations of anonymous passers-by, who seem to behave like semi-defective automata, mechanically repeating the same gestures. "Technology has subjected the human sensorium to a complex kind of training" 27 - a training aiming at developing reflexes rather than reflexivity. Capitalism knows how to profit from this ability to react immediately to stimuli:

In working with machines, workers learn to coordinate 'their own movements with the uniformly constant movements of an automaton'. ${ }^{28}$

Economy of movements, of time, of space is the key to efficiency, so that every superfluous mediation, slowing down the process of incorporation, has to be eliminated. Indeed, efficiency does not rely on rational thinking, based on the understanding of the whole system, but on the human being's ability to mimic gestures and to perform them accurately without the mediation of consciousness. The human physis is trained to resemble the infallible body of the robot, animated by no specific fears or desires, yet always ready to react. Here also the primary eccentricity of the human body is reactivated: its ability to quickly adapt to new tasks relies on the splitting of the organic unity into a series of functioning entities. When labour is segmented into a layout of extremely simple and limited tasks, the best worker is the one who is able to master one single gesture to perfection. This mastering can be achieved only through the dislocation of the individual's body - privileging in each worker one body part and its resources to the detriment of the body as a functioning whole. The trained body parts are then reassembled around the assembly line, which secures the coherence of this supraindividual body. The intangible totality of the organism thus gives way to a strategically constructed mechanism generating profit. The social and economical 'training' is complete when the self and its biological substrate - the organism - are transcended into the highly functional collective 'body' of factory workers. The structure of this body is given by the planned segmentation of work, relayed by the means of production, each machine making out of each gesture a specific step in the production process - the conveyor belt serving as the spinal column. If each worker, as an isolated limb, cannot grasp the shape of this new body, the engineers governing labour segmentation can.

16 The cross-reading of Georg Simmel's writings on the alterations of perception in late modernity and of Karl Marx's analysis of the process of hybridisation between humans and machines in factories allows Benjamin to develop a critical, historically situated reflection on the constitution of collective bodies in late modernity. Life in a capital - life under capitalism - results in the creation of collective bodies; not, however, in the 
creation of collective egos. Exploitation is indeed based on the destruction of the workers' physical integrity and on the splitting of their psychophysical unity: the body of the workers is organised, activated and controlled - possessed - by an extrinsic ego. Hence, in History and Class-Consciousness (1923), Georg Lukács insists on the necessity for the workers to build a class-consciousness establishing them as a collective subject - the proletariat a proposition widely accepted in the Marxist tradition. Benjamin makes concessions to this interpretation, ${ }^{29}$ yet he also explores a different path. He does not look, primarily, for the means to restore the psychophysical unity on a collective level, but rather seeks to disclose the revolutionary potential of a collective body freed from its allegiance to the ego - of a radically 'eccentric' body. In order to loosen the theoretical bond linking collective bodies to collective subjectivities, he takes up his early thoughts on the fundamental heterogeneity between the self and the body and focuses on the self-less collective bodies born in capitalist modernity.

17 These anonymous bodies are designated by Benjamin as the masses. By resorting to the equivocal, seemingly a-political notion of mass, Benjamin attempts to overcome the representation of collective agents as collective subjects. Adorno praises this strategic shift in a letter written a few months before the one containing the harsh criticism of his friend's 'undialectical ontology of the body':

I find your few sentences concerning the disintegration of the proletariat into 'masses' through the revolution to be amongst the most profound and most powerful statements of political theory I have encountered since I read State and Revolution..$^{30}$

What Adorno seems to miss is the link between Benjamin's theory of the revolutionary masses and his reflection on corporeality, notably the link to his early observation of the body's fundamental 'eccentricity'. The masses Benjamin describes in The Arcades-Project, in "The Work of Art in the Age of its Technological Reproducibility", and in his essay on Baudelaire are not bound together by the awareness of sharing similar features and pursuing the same goals. Yet they share a common environment, the capitalist metropolis, where they incorporated a series of reactions, enabling them to fluidly match their movements without communicating and to fuse as a body without an ego. Peter Fenves remarkably sums up Benjamin's conception of the masses as agents without strategies:

[they] solve [...] the tasks at hand without knowing what [they are] doing, indeed without realizing that there are tasks in the first place, and above all, without recognizing [themselves] as such: as 'the masses'. ${ }^{31}$

Because they have no centre of command, an affect can suddenly spread in their bodies through peripheral contagion and determine the course of collective action. In the short text "Beautiful Dismay" ("Schönes Entsetzen"), describing the celebration of the 14th of July in Paris, Benjamin portrays the passive crowd of onlookers as a dormant monster. The contradictory affects of panic and delight that run through the gathered mass, threaten to wake the monster and to trigger a revolutionary outburst. ${ }^{32}$ The masses indeed appear as "compact", monolithic formations "only from the outside, in the minds of its oppressors", ${ }^{33}$ but from the inside of their bodies, they turn out to be formless, highly unstable entities, loaded with energy and hypersensitive. 


\section{II.2. Freeing the Body from its Image. Emancipation through Distraction}

20 Mapping the territory of the mass - giving an anatomy to this unpredictable, monstrous body - becomes the key concern of the ones standing outside it. Benjamin analyses two ways of giving a structure to the body of the mass, without ever explicitly linking them: firstly, representing it as an allegory, i.e. as a collection of meaningful fragments, and, secondly, portraying it as a closed organism. Allegorising the masses is the task of the flâneur - a 'type' incarnated, in the eyes of Benjamin, by Charles Baudelaire. The flâneur stands on the threshold of his class: a member of the bourgeoisie, he willingly gives up the cosiness of his private home and dives into the masses. Yet he never fuses with them, but, rather, tries to decipher them like a mysterious rebus. As a physiognomist he attempts to construct a symbolical anatomy of the mass by identifying, through a dialectic of diversity and uniformity, several significant fragments in its body. When the flâneur "goes botanizing on the asphalt", ${ }^{34}$ he is driven by both aesthetical pleasure and epistemological interest. August Sander's portrait-atlas of the society of the Weimar Republic, which Benjamin praises in his "Little History of Photography" (1931), can be considered as a striking example of this fragmentation of the social body into a series of visual archetypes, aiming at being both aesthetically pleasurable and sociologically relevant. However, the flâneur's relationship to his object is deeply ambivalent: his distanced attitude is mingled with strong affects of fascination and repulsion. The masses indeed do not only appear to him as an object of knowledge and of contemplation, but also as a sexual fetish: the constantly exposed and yet elusive body of the masses mirrors the way in which the commodity fuels the desire of the consumer. Because the massproduced commodity is multiplied to infinity, it can be bought by anyone but possessed by no one: its inaccessibility is paradoxically based on its absolute availability. In this respect, the body of the masses, like the commodity, constantly escapes the flâneur's scrutinizing gaze - so that he "goes away empty-handed", ${ }^{35}$ as did the baroque allegorist.

21 The flâneur's objectifying gaze - be it pseudo-scientific, aesthetical or erotic - never perceives the mass as a political agent. He does not interpret his ambiguous relationship to the mass as the reflection of socio-economical antagonisms and is therefore fundamentally unable to understand it. According to Benjamin, this is not the case, however, for the fascist leader, who, like the flâneur, tries to shape the body of the masses, but with a decisively political purpose:

Fascism attempts to organize the newly proletarianized masses while leaving intact the property relations which they strive to abolish. ${ }^{36}$

The fascist method for subduing the masses rests on the transfiguration of their shapeless, uncontrollable body into a closed whole, i.e. into a recognizable, strictly outlined form endowed with an unalterable identity. The fascist propaganda does not content itself with projecting the body of the dictator on every street-corner, in every cinema, and in every household, it also enables the masses to "come face to face with themselves" - to gain access to an image of themselves. "In great ceremonial processions, giant rallies and mass sporting events", ${ }^{37}$ fascism shapes the body of the masses as a photogenic face and then offers this very mass its own image as an object of contemplation. Originally a shapeless entity, it becomes a structured, autarkic totality 
under the fascist camera-eye. Fascinated and paralysed by its own image as by a caput medusae, the "compact mass" 38 is drained of its revolutionary energy.

Is the collective body of the masses destined to fall prey to the normative images produced by fascist propaganda? Is the plastic body of mankind, which knows of no self and no other, a dream made obsolete by the reality of the racist masses, keen on defining themselves as biological organisms for which the other is always a parasite? Or can the body's 'eccentricity' be won for the revolution, as Benjamin hopes? In his essay “ Surrealism: The Last Snapshot of the European Intelligentsia" (1929), Benjamin sketches in quite an enigmatic way - the political utopia of an 'image space' (Bildraum) becoming a 'body space' (Leibraum). This transformation of a representational space into an immanent lived space is meant to lead to the "bodily innervation" of the revolutionary masses, which is defined by Benjamin as

the space, in a word, in which political materialism and physical creatureliness share the inner man, the psyche, the individual, or whatever else we wish to throw to them, with dialectical justice, so that no limb remains untorn. ${ }^{39}$

Benjamin describes here a symbolical dismemberment through which the human being's own body abolishes its centre and overthrows the established hierarchies between psyche and body, inside and outside, self and other. The only images able to activate the body's 'eccentricity' are haptic images mobilising the tension between the senses of touch and sight. The human being's environment must become a paradoxically tactile 'image space' delivering intoxicating visual shocks. Benjamin's passionate interest in photomontage and film editing has to be understood in this context: these processes create images which do not rely on a passive and concentrated reception, but on a distracted one.

"Reception in distraction" 40 is a keyword in Benjamin's theory of a political aisthesis. It has to be understood according to the polysemy of the German word Zerstreuung, meaning both a lack of concentration and a spatial scattering: the sensations of physical dislocation and of psychical distraction condition one another. In this respect, Walt Disney's or Charlie Chaplin's films produce the opposite effect of the fascist propaganda. Instead of giving the collective body of moviegoers a 'face' - a recognisable identity these films produce collective reactions - typically laughter - which bind the public together on an affective level without resorting to a normative schema. What is narrated on screen is of little importance, it is actually the formal principle of montage which produces images full of internal tensions. Overcoming the visual, i.e. representative, paradigm, these haptic images contribute to the 'bodily innervation' of the collective by creating shared physical reactions that disrupt the organic shell of the individual. A distracted mass is not a set of scattered individuals, but an anarchic, shapeless body without an ego. Neither subject nor object, this body can, in Benjamin's mind, be the matrix of a truly revolutionary movement, because, escaping every attempt at artistic and political representation, it is able to emancipate itself without even intending to do so.

\section{Conclusion}

The core of Walter Benjamin's theory of emancipation resides in his attempt to think of self-alienation - of alienation from the self - as potentially productive. The disintegration of the ego's organic substrate, induced by capitalist conditions of production and modern living conditions, makes way for the constitution of 'eccentric' collective bodies, 
irreconcilable with the organicist model of the individual defined by a precise structure and stable identity. Because he conceives of emancipation not as a process of individual enlightenment, but as a sudden, collective movement, Benjamin abandons the key concepts of the philosophies of consciousness, whose centre of gravity is the subject. The 'anthropological materialism', which Adorno feels so uncomfortable with, does not rely on a blind faith in the agency of the body, but on the critical phenomenology of embodiment that Benjamin first sketched in the late 1910s. Unlike Scheler and Husserl, however, Benjamin stresses the fundamental 'eccentricity' of the human being's body, which undermines every attempt to conceive of the body as a closed entity centred on the 'self'. The body, split between the 'lived body' (Leib) and the 'thing-body' (Körper), torn between the ego and the world, disrupts the boundaries of the supposedly autonomous individual. Benjamin conceives of the revolutionary collective according to this unpresentable model: not as a collective subject but as a collective body - as a plastic entity whose political agency relies on its ability to virtually incorporate everyone and everything.

\section{BIBLIOGRAPHY}

ADORNO, Theodor W. \& BENJAMIN, Walter, The Complete Correspondence, 1928-1940, ed. Henri Lonitz, trans. Nicholas Walker (Cambridge, MA: Harvard University Press, 2001).

BENJAMIN, Walter, Gesammelte Schriften IV, ed. Tillman Rexroth (Frankfurt/ Main: Suhrkamp, 1991).

BENJAMIN, Walter, Gesammelte Schriften VI, eds. Rold Tiedemann \& Hermann Schweppenhäuser (Suhrkamp: Frankfurt/ Main: 1991).

BENJAMIN, Walter, The Correspondence of Walter Benjamin: 1910-1940, eds. Theodor W. Adorno \& Gershom Scholem, trans. Manfred R. Jacobson \& Evelyn M. Jacobson (Chicago: University of Chicago Press, 1994).

BENJAMIN, Walter, Selected Writings 1, 1913-1926, eds. Marcus Bullock \& Michael W. Jennings (Cambridge, MA: Belknap Press of Harvard University Press, 1996).

BENJAMIN, Walter, Selected Writings 2.1, 1927-1930, eds. Howard Eiland, Michael W. Jennings \& Gary Smith (Cambridge, MA: Belknap Press of Harvard University Press, 1999).

BENJAMIN, Walter, Selected Writings 3, 1935-1938, eds. Howard Eiland \& Michael W. Jennings (Cambridge, MA: Belknap Press of Harvard University Press, 2006).

BENJAMIN, Walter, Selected Writings 4, 1938-1940, eds. Howard Eiland \& Michael W. Jennings (Cambridge, MA: Belknap Press of Harvard University Press, 2003).

BENJAMIN, Walter, The Origin of German Tragic Drama, trans. John Osborne (London: Verso, 1998).

BENJAMIN, Walter, The Work of Art in the Age of Its Technological Reproducibility, and Other Writings on Media, eds. Michael W. Jennings, Birgid Doherty \& Thomas Y. Levin (Cambridge, MA: Harvard University Press, 2008). 
FENVES, Peter, "Is there an Answer to the Aestheticizing of the Political?", in: Walter Benjamin and Art, ed. Andrew Benjamin (London/New York: Continumm, 2005).

GREIERT, Andreas, Erlösung der Geschichte vom Darstellenden: Grundlagen des Geschichtsdenkens bei Walter Benjamin 1915-1925 (München: Wilhelm Fink, 2011).

HUSSERL, Edmund, Ideas Pertaining to a Pure Phenomenology and to a Phenomenological Philosophy: Studies in the Phenomenology of Constitution, trans. Fred Kersten (Dordrecht/Boston: Kluwer, 1989).

RICHTER, Gerhard, Walter Benjamin and the Corpus of Autobiography (Detroit: Wayne State University Press, 2000).

SCHELER, Max, Formalism in Ethics and Non-formal Ethics of Value, trans. Manfred Frings \& Robert Funk (Evaston: Northwestern University Press, 1973).

SCHMITZ, Hermann, Der Leib (Berlin/Boston: De Gruyter, 2011).

STEINER, Uwe, “The True Politician: Walter Benjamin's Concept of the Political”, in: New German Critique, No. 83 (Spring-Summer 2001), pp. 43-88.

WEIGEL, Sigrid (ed.), Body- and Image-Space (London: Routledge, 1996).

WOHLFARTH, Irving, "Walter Benjamin and the Idea of a Technological Eros: A tentative reading of 'Zum Planetarium"', in: Perception and Experience in Modernity, ed. Helga Geyer-Ryan (Amsterdam/New-York: Rodopi, 2002).

WOHLFARTH, Irving, "Les noces de Physis et de Techne. Walter Benjamin et l'idée d'un matérialisme anthropologique”, in: Cahiers Charles Fourier, No. 21 (2011), pp. 121-130.

WOHLFARTH, Irving, “'Spielraum'. Jeu et enjeu de la 'seconde technique' chez Walter Benjamin”, in: Anthropologischer Materialismus und Materialismus der Begegnung. Vermessungen der Gegenwart im Ausgang von Walter Benjamin und Louis Althusser, eds. Marc Berdet \& Thomas Ebke (Berlin: Xenomoi Verlag, 2014), pp. 75-141.

\section{ENDNOTES}

1. Theodor W. Adorno \& Walter Benjamin, The Complete Correspondence, 1928-1940, ed. Henri Lonitz, trans. Nicholas Walker (Cambridge, MA: Harvard University Press, 2001) p. 146-147.

2. Although no systematic study has been dedicated to this theme, the following texts have looked into some important aspects of it: Irving Wohlfarth, “'Spielraum'. Jeu et enjeu de la 'seconde technique' chez Walter Benjamin”, in: Anthropologischer Materialismus und Materialismus der Begegnung. Vermessungen der Gegenwart im Ausgang von Walter Benjamin und Louis Althusser, eds. Marc Berdet \& Thomas Ebke (Berlin: Xenomoi Verlag, 2014), pp. 75-141; Irving Wohlfarth, "Les noces de Physis et de Techne. Walter Benjamin et l'idée d'un matérialisme anthropologique", in: Cahiers Charles Fourier, No. 21 (2011), pp. 121-130; Irving Wohlfarth, "Walter Benjamin and the Idea of a Technological Eros: A tentative reading of 'Zum Planetarium”, in: Perception and Experience in Modernity, ed. Helga Geyer-Ryan (Amsterdam/New-York: Rodopi, 2002), pp. 65-109; Uwe Steiner, “The True Politician: Walter Benjamin's Concept of the Political”, in: New German Critique, No. 83 (Spring-Summer 2001), pp. 43-88; Gerhard Richter, Walter Benjamin and the Corpus of Autobiography (Detroit: Wayne State University Press, 2000); Sigrid Weigel (ed.), Body- and Image-Space, (London: Routledge, 1996).

3. Walter Benjamin, "Surrealism: The Last Snapshot of the European Intelligentsia", in: Selected Writings 2.1, 1927-1930, eds. Howard Eiland, Michael W. Jennings \& Gary Smith (Cambridge, MA: Belknap Press of Harvard University Press, 1999), p. 217. 
4. For a sketch of this evolution, see: Hermann Schmitz, Der Leib (Berlin/ Boston: De Gruyter, 2011), pp. 147-173.

5. Uwe Steiner, “The True Politician: Walter Benjamin's Concept of the Political”, in: New German Critique, No. 83 (Spring-Summer 2001), p. 57.

6. Max Scheler, Formalism in Ethics and Non-formal Ethics of Value, trans. Manfred Frings \& Robert Funk (Evaston: Northwestern University Press, 1973), p. 399.

7. Ibid., p. 400.

8. Ibid.

9. Edmund Husserl, Ideas Pertaining to a Pure Phenomenology and to a Phenomenological Philosophy: Studies in the Phenomenology of Constitution, trans. Fred Kersten (Dordrecht/Boston: Kluwer, 1989), p. 165.

10. Ibid., p. 167.

11. Ibid., p. 157.

12. Walter Benjamin, "Wahrnehmung und Leib”, in: Gesammelte Schriften VI, eds. Rold Tiedemann \& Hermann Schweppenhäuser (Suhrkamp: Frankfurt/Main: 1991), p. 67. I rely here on Gerhard Richter's translation. (Cf. Gerhard Richter, Walter Benjamin and the Corpus of Autobiography [Detroit: Wayne State University Press, 2000], p. 61.)

13. Walter Benjamin, "Über das Grauen", in: Gesammelte Schriften VI, eds. Rold Tiedemann \& Hermann Schweppenhäuser (Suhrkamp: Frankfurt/Main: 1991), p. 76. [Richter's translation]

14. Benjamin, "Wahrnehmung und Leib", p. 67. [Richter's translation]

15. Ibid., p. 76. [Richter's translation]

16. Walter Benjamin, "Outline of the Psychophysical Problem", in: Selected Writings 1, 1913-1926, eds. Marcus Bullock \& Michael W. Jennings (Cambridge, MA: Belknap Press of Harvard University Press, 1996), p. 393.

17. Ibid., p. 394.

18. Walter Benjamin, “Theological-Political Fragment”, in: Selected Writings 3, 1935-1938, eds. Howard Eiland \& Michael W. Jennings (Cambridge, MA: Belkanp Press of Harvard University Press), p. 305.

19. Benjamin, "Outline of the Psychophysical Problem", p. 393.

20. Ibid., p. 395.

21. Benjamin, “Theological-Political Fragment”, p. 306

22. Walter Benjamin, The Correspondence of Walter Benjamin: 1910-1940, eds. Theodor W. Adorno \& Gershom Scholem, trans. Manfred R. Jacobson \& Evelyn M. Jacobson (Chicago: University of Chicago Press, 1994), p. 276.

23. Walter Benjamin, The Work of Art in the Age of Its Technological Reproducibility, and Other Writings on Media, eds. Michael W. Jennings, Birgid Doherty \& Thomas Y. Levin (Cambridge, MA: Harvard University Press), p. 32.

24. Walter Benjamin, "On Some Motifs in Baudelaire", in: Selected Writings 4, 1938-1940, eds. Howard Eiland \& Michael W. Jennings (Cambridge, MA: Belknap Press of Harvard University Press, 2003), p. 319.

25. Ibid., p. 326.

26. Ibid., p. 328.

27. Ibid., p. 326.

28. Ibid., Benjamin quotes Marx.

29. Georg Lukács' History and Class-Consciousness undeniably plays an important role in Benjamin's reception of Marx. (Cf. Andreas Greiert, Erlösung der Geschichte vom Darstellenden: Grundlagen des Geschichtsdenkens bei Walter Benjamin 1915-1925 [München: Wilhelm Fink, 2011], pp. 451-466.) Nonetheless, Benjamin's ambivalence towards the concept of class consciousness comes to the fore in a footnote of the second version of "The Work of Art in the Age of its Technological Reproducibility". Benjamin resorts to the Marxist-Leninist topoi mobilised by "communist 
tacticians" - "enlightened form of class-consciousness", "class-conscious cadres" etc. Yet in the same footnote where he praises the revolutionary strategies implemented by proletarian cadres in order to transform the mass into a class "obey[ing] a collective ratio", he defines revolution as the "loosening" of a previously "compact" (i.e. manipulable) mass - an event occurring "within the space of seconds" inside the body of the mass itself. (Walter Benjamin, "The Work of Art in the Age of Its Technological Reproducibility", p. 50-51.)

30. Adorno \& Benjamin, "The Complete Correspondence", p. 132-133.

31. Peter Fenves, "Is there an Answer to the Aestheticizing of the Political?", in: Walter Benjamin and Art, ed. Andrew Benjamin (London/New York: Continumm, 2005), p. 69.

32. Walter Benjamin, "Schönes Entsetzten", in: Gesammelte Schriften IV, ed. Tillman Rexroth (Frankfurt/Main: Suhrkamp, 1991), p. 434-435.

33. Benjamin, "The Work of Art in the Age of Its Technological Reproducibility", p. 50 [my emphasis.]

34. Walter Benjamin, "The Paris of the Second Empire in Baudelaire", in: Selected Writings 4, 1938-1940, eds. Howard Eiland \& Michael W. Jennings (Cambridge, MA: Belknap Press of Harvard University Press, 2003), p. 19.

35. Walter Benjamin, The Origin of German Tragic Drama, trans. John Osborne (London: Verso, 1998), p. 233.

36. Walter Benjamin, "The Work of Art in the Age of its Technological Reproducibility (Second Version)", in: Selected Writings 3, 1935-1938, eds. Howard Eiland \& Michael W. Jennings (Cambridge, MA: Belknap Press of Harvard University Press, 2006), p. 121.

37. Ibid., p. 132.

38. Benjamin, "The Work of Art in the Age of Its Technological Reproducibility", p. 51.

39. Benjamin, "Surrealism", p. 217.

40. Benjamin, "The Work of Art in the Age of its Technological Reproducibiltiy (Second Version)", p. 120.

\section{ABSTRACTS}

In the late 1910s and early 1920s, Walter Benjamin writes a set of fragments providing an original insight into bodily awareness and embodiment. Rejecting the natural-scientific conception of the body as organism, Benjamin implicitly resorts to the phenomenological method to grasp this elusive 'object', which pertains to the ego (as 'lived body' - Leib) and to the world (as 'thing-body' - Körper). Yet, contrary to Max Scheler and Edmund Husserl, Benjamin does not try to bridge the gap between the objective and subjective modes of appearance of the body. He instead exploits the rift that the philosophical splitting of the body opens in the individual in order to overcome the boundaries on which the concept of identity is grounded. This early phenomenology of embodiment sheds light on Benjamin's distinctive reception of Marxism, notably on the utopia of a revolutionary collective physis sketched in the late 1920s and in the 1930 s.

\section{INDEX}

Keywords: body, subjectivity, anthropology, phenomenology, emancipation, Benjamin Walter, Husserl Edmund 
AUTHOR

LÉA BARBISAN

Université Paris-Sorbonne/ Centre Marc Bloch 